\title{
Efficiency in the Criminal Procedure for Juveniles and the Protection of the Dignity of Juveniles
}

\author{
Dr. Sc. Hashim Çollaku \\ Mr.sc. Mentor Çollaku \\ 20000 Prizren, Rr. Bajo, Topulli nr. 6, Republika e Kosovës \\ hashimqollaku@hotmail.com
}

\section{Doi:10.5901/jesr.2015.v5n1s1p49}

\begin{abstract}
Criminal-procedure law is characterized by four stages of development: the investigative stage, the stage of the indictment and the defendant's statement, the trial stage and the stage with respect to remedies. The procedure for juvenile criminal offenses also goes through these stages. Juveniles participate considerably in crime, which means that society's concerns for further work are juvenile perpetrators of criminal offences. This obliges holders of responsibilities, prosecutors, judges, the police and other authorities that work to implement the legal provisions that refer to juvenile perpetrators of criminal offenses as the most sensitive categories of criminal procedure requires special attention. It works like acts and international agreements and domestic legal framework guaranteeing the rights and fundamental freedoms, which guarantee and protect the dignity of juveniles. Juvenile Justice Code was promulgated in the spirit of the Constitution of the Republic of Kosovo as well as acts of international agreements. Diversity measures oblige prosecutors and judges to new challenges in working with juvenile perpetrators of criminal offenses. In order to maintain the dignity of juvenile perpetrators of criminal offenses there should be constantly support on positive legal provisions, involving the guarding of human character, educational, economic, etc..
\end{abstract}

Keywords: carrier responsibilities in juvenile criminal proceedings, concern for society, crime prevention, criminal procedure efficiency, diversity measures, procedures for the juvenile criminal offenses, the preservation of the dignity of minors.

\section{Introduction}

The criminal legal procedure goes through those stages of development: the procedure of investigations, stage of filing of indictment and pleading of the accused, stage of main hearing and the stage about legal remedies which is the same also for juvenile perpetrators of criminal offences.

Causes of dissatisfaction led to the review of the mentioned Regulation and it was decided to rectify it by issuing the UNMIK Regulation No. 24/19991 which improved the existing Regulation. In Article 1, Item b, inter alia it reads: "the law that shall be applicable in Kosovo is valid for the laws promulgated until 22 March 1989", with other explanations until Article 2.

In the general criminality, the juveniles participate with a percentage of about $7.5 \%$ which means that the concern of the society for further work are mainly juvenile perpetrators of criminal offences. This obliges the ones responsible, prosecutors, judges, the police and other authorities to implement legal provisions at work that are related to juvenile perpetrators of criminal offences.

\section{Background of the Criminal Procedure for Juveniles in Kosovo}

After 10 June 1999, once the war was over, Kosovo was left without institutions, therefore, in order to have the function of the general social order; it was more than necessary to start with constituting provisional institutions of selfgovernance. The Provisional Administration in Kosovo started to be installed in the functioning of the governance starting from the legislative and executive ones as well as the administration of justice authorities exercised by the Special Representative of the Secretary General of the United Nations (SRSG). The same Regulation also foresees the laws that will be applicable as well as the entry into force of the Regulations that would be issued by UNMIK.

Since it was seen that there was a gap and lack of clarity about application of the laws in force and in order to

1 UNMIK Regulation No. 24/1999, 12 December 1999. 
eliminate those uncertainties, the Regulation 1/99 was supplemented with Regulation 24/99 in which in Article 1, Paragraph 1.1 (b) decisively it was emphasized that "the Laws applicable in Kosovo shall be all laws that were applicable until 22 March 1989 ".

Criminal legislation was applicable in Kosovo according to UNMIK Regulation No. $1 / 99^{2}$ and $24 / 99^{3}$, which have foreseen the procedures with juvenile perpetrators of criminal offences. After the entry into force of the Criminal Code of Kosovo (hereafter referred to as CCK), the gap was noticed in relation to preparatory procedure with the juvenile perpetrators of criminal offences, therefore, there was rapid work done on the issuing of the Juvenile Justice Code of Kosovo (hereafter referred to as JJCK) 4 .

The juveniles are a sensitive category of the society; therefore, the legal infrastructure needs to be more adequate for the ones responsible - Justice Authorities and other organizations. Thought is given that juveniles as perpetrators of criminal offences with participation in general criminality should have the necessary care by the society. Based on general statistics on a state level, the participation of juvenile perpetrators of criminal offences in Kosovo is about $7.5 \% 5$. The preparatory procedure and the court hearing for juveniles require special laws for the work with juveniles. There is constant work on enhancement of the legislation. In pursuit of this issue, it was the task of the respective authorities to work on arrangement of JJCK as to the substantive and procedural side. During the work, the difficulties in application of JJCK are identified and after the identification of deficiencies and uncertainties, this lead to promulgation of the Juvenile Justice Code $^{6}$ (hereafter referred to as JJC). With this law promulgated, it is thought that the best solution has been done.

Special care has been shown to the category of juvenile persons as a special procedure has been conducted also according to the laws that were applicable in the inexistent state, former Yugoslavia. Legal provisions that referred to the work with the juveniles were foreseen in the Law on Criminal Procedure of the SFRY (LCP) ${ }^{7}$, which has abolished the LCP that was applicable according to the official gazettes of SFRY No. 50/67, 54/70 and 6/73. Rules based on this Law and other provisions are in contradiction with LCP according to the official gazette of the SFRY No. 26 dated 16 May 1986 entered into force with LCP, Chapter 27 according to the legal provisions that refer to the criminal procedure for juveniles ${ }^{8}$ adapting other legal provisions during the work.

Considering this fact, it is necessary that the human rights and freedoms are guaranteed with legal infrastructure. This means that the juveniles too should have the fundamental rights and freedoms like the right for life, for education, for communication, for freedom of expression etc., because denying these rights put them in an inferior position.

Also other international instruments and acts that need to be in force have been foreseen which refer to the guaranteeing of Fundamental Human Rights and Freedoms, with special emphasis by protecting the personality and integrity of the juveniles. Special emphasis here is the International Convention on the Rights of the Children dated 20 December 1989.

The work of courts and prosecution offices in Kosovo started with the mentioned Regulations foreseeing ad hoc courts and ad hoc prosecution offices with the mentioned legal framework. All Regulations issued by the SRSG were valid for the whole territory of Kosovo until the promulgation of JJCK without excluding the other international instruments and acts.

There was no Criminal Code for Juveniles in Kosovo but the laws and other international instruments and acts that were in force in the inexistent state were applicable until the promulgation of the Criminal Procedure Code of Kosovo $(\mathrm{CPCK})^{9}$, Criminal Code of Kosovo $(\mathrm{CCK})^{10}$, so that there is no legal vacuum. With the suggestion of local and international experts, the procedure for promulgation of JJCK was expedited in order to protect the work with the juvenile perpetrators of criminal offences as to the procedural aspect.

Promulgation of JJCK marks an important era in the work of the justice authorities like prosecution offices and courts as Kosovo had its JJCK for the first time enabling the regulation of the work of the Justice authorities with special

\footnotetext{
2 UNMIK Regulation No. 1/1999 dated 25 June 1999, on the Authority of the Interim Administration in Kosovo.

3 UNMIK Regulation No. 24/1999, 12 December 1999, on the Law Applicable in Kosovo.

4 UNMIK Regulation No. 2004/8 dated 20 April 2004.

${ }_{5}^{5}$ Perpetrators of criminal offences reported by the police reach the number of 8.000 cases, just for information, from 01 January 2007 to 31 March 2009, there were 8.280 cases reported where perpetrators of criminal offences were juveniles ${ }^{5}$.

6 Juvenile Justice Code No. 03/L-193

7 Official Gazette of SFRY No. 4/77 dated 01 July 1977.

8 The same, Article 452-492 of LCP.

9 UNMIK Regulation No. 26/2003 dated 6 July 2003
}

10 UNMIK Regulation No. 25/2003 dated 6 July 2003. 
laws. Of course the part of the work on JJCK and of the ones in charge for Justice Authorities were also the other legal provisions of CPCK, and international instruments and acts which need to be applied while exercising the work.

JJCK, which is in force since 20 April 2004, in its content, has foreseen five parts, each of them with its own characteristics.

JJCK is drafted in the spirit of international instruments and acts by not excluding the Instructions of the United Nations on the Prevention of Juvenile Delinquency (Riyadh Instructions) adopted and published with the Resolution 45/112 of the General Assembly on 14 December 1999, 68th plenary session, Minimal Standard Rules for Nonpunishment Measures (Tokyo Rules) adopted with the Resolution 45/110 of the General Assembly on 14 December 1990, Minimal Standard Rules of the United Nations for Justice Administration for Juveniles (Beijing Rules) adopted with the Resolution 40/33 of the General Assembly in November 1985. As a novelty in JJCK and in the spirit of this instructions and regulations, an integral part of this code were foreseen to be also the diversity measures as part of criminal sanctions that could be imposed to juveniles along with educative measures and other punishments ${ }^{11}$. Diversity measures are imposed to juvenile perpetrators of criminal offences in order to prevent when there is legal possibility not to start with the criminal procedure against the juvenile perpetrator for criminal offences and in order to assist in rehabilitation and reintegration in the society so that the deviating behaviors are not repeated.

As to the JJC, which is in force since 08 July 2010, it differs from JJCK which was applicable until the promulgation and entry into force of JJC, which foresees six dividend parts in 22 chapters. Part one - Guiding Principles and introductory provisions, Part two - Applicable Measures and punishments, part three - Procedure, part four - Mediation and execution of measures and punishments, part five - proceedings involving criminal offences committed against children, part six - transitional and final provisions.

\section{Main Characteristics in the Preparatory Procedure for Juveniles}

Before initiation of the preparatory procedure, a prosecutor should eliminate the dilemma whether the criminal offence is punishable with a imprisonment sentence up to 3 years or with a fine in order to decide for the imposition of the diversity measure, otherwise shall start the procedure for issuing the ruling on initiation of the preparatory procedure. Then, the prosecutor starts with collection of necessary evidences that follow the criminal case respecting the rights and freedoms guarantied with positive local laws and other international acts and instruments.

It is important that if the juvenile while commission of the criminal offence was under the age of 18 , then after the age of 18 until the age of 21 the procedure will be conducted as if he/she was of the age of 18. After turning 21, the preparatory procedure is not conducted. Despite the fact that there is no adequate legal provision based on judicial practice, the practice is that for the persons who have committed criminal offences until the age of 18 and the procedure is not finished, the procedure is then terminated.

There is a possibility that a prosecutor does not finish the preparatory procedure; he/she may ask for extension of the preparatory procedure for a legal period of time ${ }^{12}$. Depending on the nature of the case, a prosecutor decides for one of the measures foreseen for ensuring the presence of the reported juvenile ${ }^{13}$ and depending on the measure decided, the provisions of CPCK are applied mutatis mutandis. But special care should be shown to the reported juvenile as the detention is initially decided for duration of one month and may be extended with the proposal of the state prosecutor for another 2 months.

So, the duration of the detention cannot be more than 3 months in the preparatory procedure whereas while in the detention center, the juvenile should not be kept together with adult detainees as is negatively affected in the personality of the juvenile.

During the preparatory procedure after all collected evidences are evaluated, after the conclusion of the preparatory procedure the prosecutor issues the proposal for imposition of the educative measure or the proposal for imposition of the punishment, depending on the circumstances in the flow of the criminal case. The juvenile judge should be notified for each document, collected evidence, and proposal coming from the parties interested in the procedure, during the preparatory procedure.

After it is considered that it is over with the collection of evidences and the juvenile judge as well as the defense counsel of the juvenile and the juvenile is notified about it, the prosecutor evaluates the collected evidence and decides for proposal of imposition of educative measure or proposal for announcement of the punishment.

\footnotetext{
${ }^{11}$ Article 6 Paragraphs 1 and 2 of JJCK

${ }^{12}$ Article 59 of JJCK and Article 159 of CPCK.

${ }^{13}$ Chapter X, from Article 161 of CPCK.
} 
The state prosecutor files the proposal for imposition of the educative measure against a juvenile who at the time of the commission of the criminal offence is not of the age of 16 so that the juvenile is given the possibility to improve and be reintegrated in the society with the belief that the proposed measure would have effect on the juvenile and that the wanted effect would be achieved but depending on the type of the criminal offence the possibility of proposal of such type is not limited also for juvenile perpetrators of criminal offences who are over this age.

The proposal for announcement of the punishment, proposed by the prosecutor, is filed after the legal conditions are met against the juvenile perpetrator of a criminal offence who at the time of commission of the criminal offence is of the age of 16 . This circumstance should be proved during the course of the preparatory procedure.

The proposals foreseen in the JJC should be justified with the evidences that are collected and evaluated so that the criminal case is presented in an adequate manner and in line with the legal framework, otherwise, the juvenile judge may decide to dismiss the proposal filed at the court as inappropriate for further work or to return it for supplementation.

If the juvenile has committed a criminal offence together with an adult, the public prosecutor files the proposal for joinder of the criminal procedure with the adult. The trial panel of the competent court decides on this.

When the foreseen legal conditions are fulfilled, the work is continued at further stages as foreseen, like, initiation of the court hearing by the juvenile judge of the respective court and the participation of the prosecutor is mandatory.

For the efficiency of the criminal procedure, the prosecutor decides for one of the measures for ensuring the presence of the reported juvenile as foreseen with the legal provisions of the CPCK which are applied mutatis mutandis also for juveniles. Detention can also be imposed against a juvenile which initially is imposed with a duration of one month and may be extended for another 2 months by the juvenile panel of the competent court with the proposal of the prosecutor with the intention to achieve the requested efficiency in the procedure. Detention is imposed in accordance with the legal provisions ${ }^{14}$, as a measure to ensure the presence of the juvenile in order to achieve the requested rhythm of the work.

In order to respect the dignity of the juvenile while his/her stay in the detention center ${ }^{15}$, the juvenile should not be kept at the same place with the adult detainees but the detention should be served in a respective penitentiary institution for juveniles.

The prosecutor files the proposal for imposition of educative measure against a juvenile who at the time of the commission of the criminal offence is not at the age of 16 so that the juvenile is given the possibility to improve and be reintegrated in the society with the belief that the proposed measure would have effect on the juvenile and that the wanted effect would be achieved but depending on the type of the criminal offence the possibility of proposal of such type is not limited also for juvenile perpetrators of criminal offences who are over this age.

The proposal for announcement of the punishment, proposed by the prosecutor, is filed after the legal conditions are met in line with $\mathrm{JJC}$ and is filed against the juvenile perpetrator of a criminal offence who at the time of commission of the criminal offence is of the age of 16 . This circumstance should be proved during the course of the preparatory procedure.

The preparatory procedure against the juveniles is conducted with a special care considering the juvenile against whom the procedure is conducted in order to retain the personality of the juvenile, spiritual, psychological development, sensitivity of the juvenile. When the gaps are noticed at work, the provisions of CPCK and the other international instruments and acts are applied mutatis mutandis.

In the preparatory procedure for juveniles, the prosecutor issues the ruling on initiation of preparatory procedure and from that moment he/she starts with the investigation of the criminal case for gathering of necessary evidences by applying positive legal provisions until the conclusion of investigations and decision to send the criminal case to further work. Once the criminal report is filed, it is important to determine the type of the criminal offence as the juveniles are mainly perpetrators of different types of criminal offences.

Diversity measures are foreseen in the second part, chapter four. There are 8 (eight) types of it. They are imposed by the state prosecutor through a Ruling and without conducting a preparatory procedure. This does not mean that if the diversity measure imposed did not achieve the foreseen legal effect (verified by the work of the subjects in the procedure) the preparatory procedure cannot be initiated.

${ }_{14}$ Article 187, CPCK, conditions for imposition of detention.

${ }^{15}$ Article 194 read with Article 197, of CPCK. 


\section{Efficiency in the Criminal Procedure for Juveniles and Protection of the Dignity of the Juvenile}

Starting from the United Nations Universal Declaration of Fundamental Human Rights and Freedoms ${ }^{16}$, European Convention on Human Rights ${ }^{17}$, Facultative Pact on Civil and Political Rights ${ }^{18}$, Universal Convention for Protection of the Rights of Children ${ }^{19}$, Constitution of the Republic of Kosovo ${ }^{20}$ local legal framework, Criminal Procedure Code of Kosovo (CPCK ${ }^{21}$ ), Criminal Code of Kosovo (CCK ${ }^{22}$ ) Juvenile Justice Code of Kosovo, now in force $\mathrm{JJC}^{23}$, special care is shown for the efficiency of the preparatory criminal procedure for juveniles. Respecting the international instruments and acts and the local laws increases the efficiency and protection of the fundamental human rights and freedoms, in the concrete case the dignity of the juvenile.

Juvenile perpetrators of criminal offences as the most special category in the work require privileged treatment during the work. There is a need for adequate legal infrastructure and offering of better conditions at work based on the local and international legal framework. There is a legal definition at JJC as to the juveniles so the juvenile is a person who at the time of the commission of the criminal offence was for 14 (fourteen) to 18 (eighteen) years old. The legal definition of the category of juvenile persons is also provided in the international convention.

In order to have a better efficiency, prosecution offices and courts should have sufficient number of prosecutors and judges ${ }^{24}$, and now the number of prosecutors and judges is being increased as a result of the process of reappointments and reformation of the judicial and prosecutorial systems. This is expected to improve the material status of the judges and prosecutors with the increase in their salaries.

Starting of the work of courts and prosecution offices in the territory of Kosovo has vitalized the life in the jurisprudence and there were efforts for a contribution in preventing the spreading of the criminality. With the Regulations, the work of courts and prosecution offices was of ad hoc character. The applicable law according to the Regulations issued by the SRSG is applicable in the territory of Kosovo together with other international instruments and acts.

Promulgation and entry into force of JJC marked an important achievement for the work of justice authorities as they work with a codified material which makes the further work easier. The subjects and parties in the procedure have the possibility to have better rhythm and efficiency during the work. Being equipped with the legal infrastructure, the police, judges and prosecutors shall have the possibility not to do mistakes and violate the fundamental human rights and freedoms of juveniles during the work and will protect the dignity of the juvenile. While hearing the juvenile, the guaranteed rights should be respected; otherwise, each violation is registered and poses a responsibility for a subject.

The diversity measures as a novelty in JJC, present the integral part of the work with juvenile perpetrators of criminal offence that are applied before initiation of the work on preparatory procedure with the juveniles and after finishing the work with them educative measures or other punishments are imposed. The diversity measures are

\footnotetext{
16 United Nations Universal Declaration of Fundamental Human Rights and Freedoms dated 10 December 1948.

17 European Convention on Human Rights, 1950.

18 Facultative Pact on Civil and Political Rights 1966.

19 Universal Convention for Protection of the Rights of Children 1986.

${ }^{20}$ Constitution of the Republic of Kosovo dated 9 April 2008, in force since 15 June 2008.

${ }^{21}$ Criminal Procedure Code of Kosovo, UNMIK Regulation 26/2003, July 2003, in force since 6 April 2004.

${ }^{22}$ Criminal Code of Kosovo, UNMIK Regulation 25/2003, July 2003, in force since 6 April 2004.

23 JJCK, UNMIK Regulation No. 6/2004 dated 20 April 2004, amended with JJC since October 2010, promulgated in the spirit of international instruments and acts by not excluding the Instructions of the United Nations on the Prevention of Juvenile Delinquency (Riyadh Instructions) adopted and published with the Resolution 45/112 of the General Assembly on 14 December 1999, 68th plenary session, Minimal Standard Rules for Non-punishment Measures (Tokyo Rules) adopted with the Resolution 45/110 of the General Assembly on 14 December 1990, Minimal Standard Rules of the United Nations for Justice Administration for Juveniles (Beijing Rules) adopted with the Resolution 40/33 of the General Assembly in November 1985. As a novelty in JJCK and in the spirit of this instructions and regulations, an integral part of this code were foreseen to be also the diversity measures as part of criminal sanctions that could be imposed to juveniles along with educative measures and other punishment. Diversity measures are imposed to the juvenile perpetrators of criminal offences in order to prevent initiation of criminal procedure against the juvenile perpetrators for the criminal offences as foreseen in the law.

${ }^{24}$ Number of prosecutors with respect to the number of inhabitants. If a comparison is done between the number of prosecutors in Kosovo with the number of prosecutors from the countries in the region, the difference is as follows: in Kosovo for 100.000 inhabitants there are 3.7 prosecutors, in Bosnia and Herzegovina for 100.000 inhabitants there are 7.3 prosecutors, in Slovenia for 100.000 inhabitants there are 8 prosecutors, in Croatia for 100.000 inhabitants there are 13.0 prosecutors and in Montenegro for 100.000 inhabitants there are 13.4 prosecutors (Source: report on the programs - July 2009, page 89 on internet webpage: http://www.eulexkosovo.eu/news/docs/programmereport/EULEX-PROGRAMME-REPORT-July-2009.new-AL.pdf
} 
imposed to the juvenile perpetrators of criminal offences with the aim to prevent the initiation of preparatory measure for juveniles in cases as determined by law.

\section{Preparatory Procedure for Juveniles}

Initiation of the preparatory procedure against the juveniles is linked with the procedural principles like the principle of publicity, the principle of division of the preparatory procedure, the principle of fair trial within a reasonable time, the principle of economization etc., that directly have impact on the efficiency of the procedure. The ones in charge of responsibilities should have the necessary knowledge on implementation of the legal provisions as during the work they should care for protection of the dignity of the juvenile. All these principles follow the preparatory procedure so that the dignity of the juvenile is protected and that there is no concern that reflects negatively on the juvenile.

The preparatory procedure for juveniles starts with the initiation of the ruling on initiation of the preparatory procedure after the criminal report is assessed and offers the necessary basis for initiation of the procedure. Once the preparatory procedure is initiated, the rhythm of the work is set by coordinating actions with the other subjects in the procedure. In line with the respective provision, the on-call authority of the Center for Social Work, the Correctional Service are informed in order to receive the social inquiry as well as the other parties as mentioned in the legal provisions.

Protection of the dignity of the juvenile starts from the first contact at the police, the juvenile needs to be respected, should not be subjected to physical and psychic maltreatment, should be enabled to have contact with the legal representative - parent, his defense counsel etc., as foreseen with the legal provisions.

In line with the legal provisions of JJC, CPCK, the state prosecutor conducts the preparatory procedure, gathers the necessary evidences, evaluates them and following the conclusion of the preparatory procedure decides for filing of the proposal for imposition of educative measure or the proposal for imposition of a punishment. This obliges the prosecutor to be efficient at work.

Respecting the dignity of the juvenile during the work applies also while undertaking procedural actions, starting from interrogation, verification of the date of birth, if the juvenile was under police custody all measures should be undertaken that the juvenile is sent to the Center of Family Medicine to find out about his/her health status in relation to facing the custody and stay in the detention for the further procedure.

The following conditions should be fulfilled during the interrogation of the juvenile:

- his legal representative - parent should be present;

- if he has no parent, the adopting parent or the custodian of the juvenile should be present,

- depending on the stage of the preparatory procedure, the public prosecutor should be careful that the juvenile is assigned with a defense counsel,

- to respect all rights guaranteed that pertain in line with Article 231 of CPCK when he is in front of the prosecutor for giving a statement and if he is interviewed at the police in line with Article 214 of CPCK. The rights should be respected also when he is before the juvenile judge.

\section{The State Prosecutor in the preparatory stage for juveniles}

A juvenile is a person from 14 to 18 years old, an age that offers legal conditions for initiation of the preparatory procedure for juveniles. The preparatory procedure cannot be conducted against a juvenile person who has committed a criminal offence and has not reached the age of 14.

Categorization of persons as juvenile is foreseen with legal provisions ${ }^{25}$, in which there is an expressional definition for this category but this division of juveniles was also foreseen in the applicable laws based on which the preparatory procedure for juveniles were conducted ${ }^{26}$. JJC contains respective provisions for regulating the preparatory procedure for juveniles starting from material, procedural and provisions for execution of criminal sanctions.

The preparatory procedure against the juveniles is conducted with a special care considering the juvenile against whom the procedure is conducted in order to retain the personality of the juvenile, spiritual, psychological development, sensitivity of the juvenile. When the gaps are noticed at work, the provisions of CPCK and the other international

${ }^{25}$ Article 2, JJC

${ }^{26}$ Applicable LCP, on chapter 27 has foreseen the procedure against juveniles starting from Article 452 - 492. 
instruments and acts $^{27}$ are applied mutatis mutandis.

In the preparatory procedure for juveniles, the state prosecutor issues the ruling on initiation of preparatory procedure and from that moment he/she starts with the investigation of the criminal case for gathering of necessary evidences by applying positive legal provisions until the conclusion of investigations and decision to send the criminal case to further work. Once the criminal report is filed, it is important to determine the type of the criminal offence as the juveniles are mainly perpetrators of different types of criminal offences ${ }^{28}$

When we are at the work and development of preparatory procedure, we need to consider that the juvenile perpetrators of criminal offences are persons of different genders, they are male or female. Males in general delinquency participate with about $97 \%$ whereas females as juvenile perpetrators of criminal offence participate with $3 \%$.

According to LCP, the preparatory procedure for juveniles is initiated with the request of the prosecutor for preparatory procedure, whereas the juvenile judge has issued the ruling on initiation of the preparatory procedure who also organizes the work on collecting the necessary evidences ${ }^{29}$.

The State Prosecutor should be careful that during the preparatory procedure, he/she should respect the dignity of the reported juvenile from the first moment in the procedure, to verify the date of birth by ensuring a birth certificate, should know whether the juvenile was sent to the Center of Family Medicine to find out about his/her health status. If the case is with detention, it should be verified whether the juvenile can face the imposition of detention or not.

The juvenile should not be interrogated more than two times and the following conditions should be fulfilled during the interview of the juvenile:

- his legal representative - parent should be present;

- $\quad$ if he has no parent, the adopting parent or the custodian of the juvenile should be present,

- depending on the stage of the preparatory procedure, the public prosecutor should be careful that the juvenile is assigned with a defense counsel,

- to respect all rights guaranteed that pertain in line with the CPCK.

\title{
7. Conclusion
}

The Criminal Procedure for juveniles has many specifics which are characterized with the efficiency in protecting the dignity of the juvenile. The preparatory stage starts with the issuance of the Ruling on initiation of preparatory procedure, than goes with collection of evidences - personal and material ones.

From this point of direction, the procedure goes through the stage of preparatory procedure, the procedure of deciding to present the respective proposal, to present the subjects and parties in the main hearing and the procedure about the legal remedies.

Hence, respecting the human rights is a crucial issue as the fundamental human rights and freedoms are guaranties with the constitution and laws without excluding other international acts and instruments.

This has made the subjects and parties in the procedure to respect the rights of the juvenile starting from:

- the right for life,

- the right for identity,

- the right and freedom for expression in all types of procedure,

\begin{abstract}
${ }^{27}$ Inter alia, Minimal Standard Rules of the United Nations for Justice Administration for Juveniles (Beijing Rules) adopted with the Resolution 40/33 of the General Assembly on 29 November 1985, Instructions of the United Nations on the Prevention of Juvenile Delinquency (Riyadh Instructions) adopted and published with the Resolution 45/112 of the General Assembly on 14 December 1999, 68th plenary session, Minimal Standard Rules for Non-punishment Measures (Tokyo Rules) adopted with the Resolution 45/110 of the General Assembly on 14 December 1990.

${ }^{28}$ Criminal offences that characterize juvenile perpetrators of criminal offences are offences against life and body, chapter XXV (criminal offence of murder - Article 146 of CCK, criminal offence of aggravated murder - Article 147 of CCK, criminal offence of light bodily harm - Article 153 of CCK, criminal offence grievous bodily harm - Article 154 of CCK, criminal offence of participation in a brawl - Article 155 of CCK, criminal offences against sexual integrity, Chapter XIX (criminal offence of rape - Article 193 of CCK, criminal offence of sexual abuse of persons with mental or emotional disorders or disabilities - Article 197 of CCK, criminal offence of sexual abuse of persons under the age of sixteen years - Article 198 of CCK, etc.), criminal offences against public health - Chapter XXI (criminal offence of unauthorized purchase, possession, distribution and sale of dangerous narcotic drugs and psychotropic substances from Article 229 of CCK), criminal offences against economy - chapter XXI (criminal offence of counterfeit money - Article 244 of CCK), criminal offences against property, chapter XXII (criminal offence of aggravated theft - Article 252 of CCK, criminal offence of Robbery - Article 255 of CCK).

${ }^{29}$ Article 470, LCP
\end{abstract}


- the right for defense and defense counsel,

- not to be misused and abused during the procedures,

- to respect the interest and the dignity of the child who needs to have additional care,

- to have the right for time off and use of free time,

- to have the right to fight all forms of exploitation or discrimination,

- to have the right not to be deprived of liberty illegally and to have the legal defense,

- to have the diversity measure imposed more by prosecutors and judges during the procedure in order to increase the efficiency considering the aim of imposing those measures,

- alternative sentences foreseen in JJC should increase during the work

- social inquiry should be more all-inclusive and should not contain the proposal for imposition of eventual measure,

- placing the juvenile in detention should be as limited as possible,

- a respective service should be established in the state level for the care of children who are perpetrators of criminal offences of the age of fourteen (14) (considering the fact that we have perpetrators of criminal offences of this age, and nothing is regulated in the law as to the treatment that should be offered to this category),

- to adapt the legal provisions so that there are no difficulties at work in relation to their implementation,

- during the interrogation of the juveniles in the capacity of the reported party, injured party or witness, they should not have psychical burden that would affect the statement.

\section{References}

\section{Books and Essays}

UN Universal Declaration of Fundamental Human Rights and Freedoms, December 1948,

Convention on the Rights of a Child, 1989

European Convention on Human Rights, 1950,

Constitution of the Republic of Kosovo, Pristina, 2008

Constitution of the Republic of Albania, Tirana, 1998

Criminal Procedure Code of Kosovo, UNMIK Regulation No. 25/2003, July 2003

Criminal Code of Kosovo, UNMIK Regulation No. 26/2003, July 2003

Code of ethics and professional behavior for Kosovo prosecutors, 9 May 2005

Convention on the Rights of the Child, Adopted by General Assembly of the Unated Nations, Law on Kosovo prosecutor, Official Gazette of SAPK, 32/1976, 28 July 1976

Law on regular Courts, Official Gazette of SAPK, 21/1978, 28 April 1978 Sahiti, Ejup, Argumentation in Criminal Procedure, Tetovo 1999; Pristina 2006

Juvenile Justice Code of Kosovo, 20 April 2004,

Juvenile Justice Code of Kosovo, No 03/L-193 08 July 2010

Law No. 03/L-003 on amending and supplementing the CPCK,

Facultative Pact on Civil and Political Rights, June 1986,

Compilation of principles for the protection of all persons under any form of detention or imprisonment, approved with the Resolution of the General Assembly No. 43/173, 09 December 1998

UNMIK Regulation No. 1/1999, 25 June 1999, on the Authority of the Provisional Administration in Kosovo

UNMIK Regulation 5/1999, 4 September 1999, on the establishment of an ad hoc court of final appeal and of the ad hoc public prosecution office

UNMIK Regulation 24/1999, 12 December 1999, on the applicable law in Kosovo.

UNMIK Regulation 53/2005, 20 December 2005,

Sahiti, Ejup, The right on Criminal Procedure, Pristina, 2005

Salihu, Ismet, The Criminal Juvenile right, Pristina 2005 